\section{Holocene climatic change in Hunshandake Desert}

\author{
JIN Heling ${ }^{1,2}$, SU Zhizhu ${ }^{3}$, SUN Liangying ${ }^{1}$, \\ SUN Zhong ${ }^{1}$, ZHANG Hong ${ }^{1} \&$ JIN Liya $^{2}$
}

1. Key Laboratory of Desert and Desertification, Cold and Arid Regions Environmental and Engineering Institute, Chinese Academy of Sciences, Lanzhou 730000, China;

2. School of Resources and Environment, Lanzhou University, Lanzhou 730000, China;

3. Institute of Loess Plateau Research, Shanxi University, Taiyuan 030006, China

Correspondence should be addressed to Jin Heling (e-mail: iinhl@ns.lzb.ac.cn)

Abstract Research on the geological data of Hunshandake Desert in China monsoon region revealed that Holocene summer monsoon had experienced six prevailing periods and seven weakening periods. The climatic humidity and the vegetation had also undergone the similar periodical variation influenced by the monsoon periodicity. The period when summer monsoon prevailed or winter monsoon weakened and climatic humidity and vegetation coverage relatively increased, corresponded to the global warming events; whereas the period when summer monsoon weakened or winter monsoon prevailed and climatic humidity and vegetation coverage relatively decreased, corresponded to the arid events in middle to low latitudes and the cold events in North Atlantic. As for the changing regularity of summer monsoon intensity there were two distinct periodicities of 1456 years and 494 years, also these two periodicities had global significance.

Keywords: Hunshandake Desert, climatic change, geological data, Holocene.

\section{DOI: 10.1360/03wd0286}

Researchers all over the world attach importance to the study on the climatic and environmental changes in geological and historical time especially change in Holocene ${ }^{[1-5]}$. Further, the study on climate and paleoenvironment of millenary-level and century-level in Holocene is the hotspot in global climatic change research ${ }^{[6-9]}$. Recent research results show that the global climatic change in Holocene had obvious periodicity ${ }^{[1]}$, and there is no exception in China ${ }^{[2,3,5,9]}$. Whereas less issues on Holocene climatic change research at millenary-level and century-level were based on desert data, and desert is one of the important landscapes sensitive to climatic change, so the authors of this thesis hope to established the Holocene millenary-level climatic change processes according to the geological data of Hunshandake Desert, and to provide plentiful evidences for deeply studying the climate change history of China monsoon region. The Hunshandake Desert situates in the eastern part of Inner Mongolia (Fig.1), bestriding the semi-humid, semi-arid and arid climatic zones. The results of the former researches on the climatic and environmental changes of the desert ${ }^{[10-12]}$ can provide scientific train of thought for the authors to completely understand the Holocene climate and environment, but these researches possibly dealt with short time-span or lacked continuity of strata sequence. For solving these problems the authors have located an uninterrupted and whole stratigraphic profile, the Xilinhot profile, as the typical record of Holocene, based on the entire survey of the Hunshandake Desert.

\section{Stratigraphic sequence and chronology}

The Xilinhot profile is located in the south $7 \mathrm{~km}$ to Xilinhot City of Inner Mongolia, at about $43^{\circ} 52^{\prime} 36.6^{\prime \prime} \mathrm{N}$, $116^{\circ} 5^{\prime} 34.1^{\prime \prime} \mathrm{E}$ on geographic grid (Fig. 1). The landforms of this area are gently undulating hills covered with sand sheet. The Xilinhot profile is exposed in a W-E directional gully at about 3-4 m depth, has the thickness of $2.75 \mathrm{~m}$, which are composed of six aeolian sand layers overlapping six sandy paleosol layers, only the top aeolian sand has been eroded. Samples were sampled out in every $5 \mathrm{~cm}$ in the profile. Among the collected 56 blocks of samples there were nine blocks for age dating, among which seven from organic carbon paleosols are for ${ }^{14} \mathrm{C}$ dating, two from aeolian sand layers for TL dating. The ${ }^{14} \mathrm{C}$ Age Dating Laboratory of Resource and Environment School in Lanzhou University has measured the nine and the Guangzhou Geo-chemistry Institute of Chinese Academy of Sciences has measured the two.

Showed in the measured chronological timescale (Table 1), the two TL data at bottom of the profile are $9460 \pm 900$ and $10700 \pm 920 \mathrm{aBP}$ respectively. In field survey a thaw fold layer was found in a stratigraphic profile at $200 \mathrm{~m}$ eastward from the Xilinhot profile. Viewed from stratigraphic correlation the thaw fold layer likely correlated to the Younger Dryers event. The thaw fold layer paralleled the stratum below the bottom aeolian sand layer in the Xilinhot profile. Combining this correlation with the TL dating of the bottom aeolian sand, it can be confirmed that the stratum below the bottom aeolian sand layer in the Xilinhot profile was formed in Holocene. Therefore, it is absolutely credible that the deposited era of the aeolian sand at $275 \mathrm{~cm}$ depth in the Xilinhot profile was a little later than the Younger Dryers event. In order to make the ${ }^{14} \mathrm{C}$ dating ages comparable with the other Holocene research results in existence, these measured ages have been converted to calendar ages by using the Oxcal ${ }^{14} \mathrm{C}$ calibrating program provided by Stuiver et al (Table 1). According to the calendar ages the depositional eras of stratigraphic sequence have been calculated through making use of both the interpolation method based on depositional rate and the Kukla method ${ }^{[13]}$ based on magnetic susceptibility (Fig. 2). Comparison results of these two methods showed that the interpolation method had larger error of calculated ages resulting from distinct 


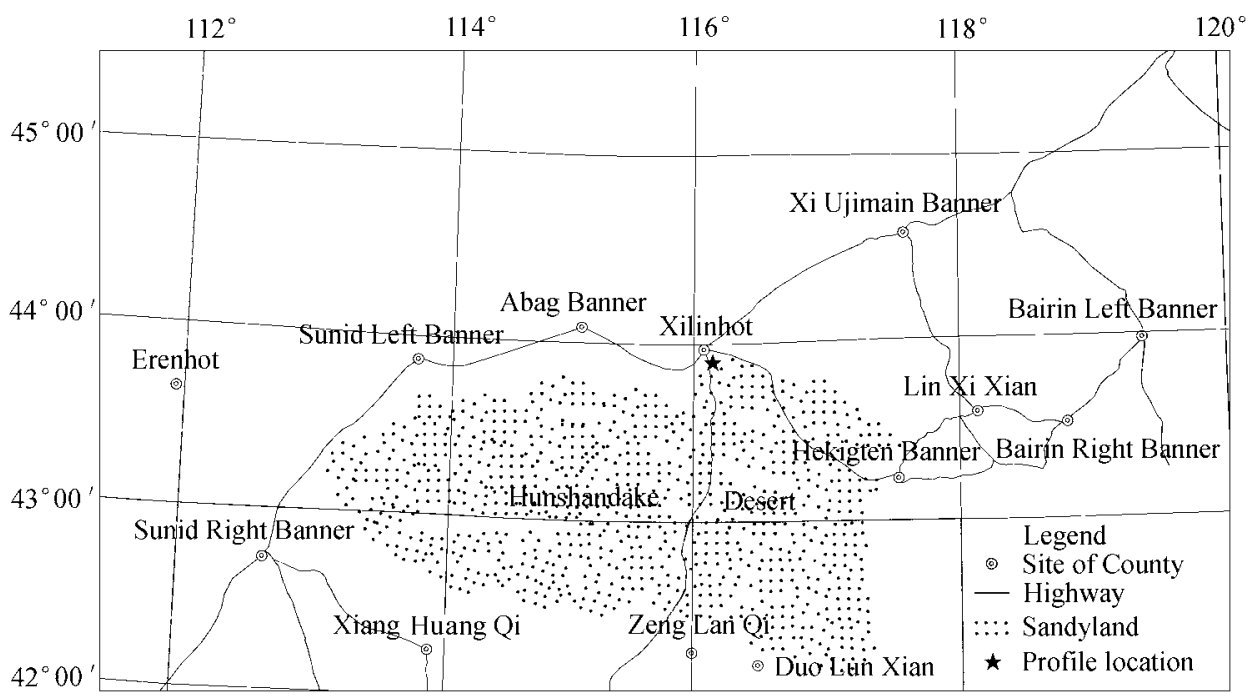

Fig. 1. Location of the Xilinhot profile in Hunshandake Desert.

differences of depositional rate between paleosol and aeolian sand, whereas the Kukla method has taken these into consideration, so the calculated ages are relatively credible, and this method has been proved to be very successful for studying the Chinese Loess Plateau.

Table 1 Measured stratigraphic ages and the calibrated results

\begin{tabular}{|c|c|c|c|c|c|c|c|c|c|}
\hline \multirow[t]{2}{*}{$\begin{array}{l}\text { Depth } \\
\text { /cm }\end{array}$} & \multicolumn{2}{|c|}{$\begin{array}{l}\text { Measured } \\
\text { ages/aBP }\end{array}$} & \multicolumn{2}{|c|}{$\begin{array}{c}\text { Calibrated } \\
\text { ages/cal } \\
\text { aBP }(1 \sigma)\end{array}$} & \multirow[t]{2}{*}{ Depth/cm } & \multicolumn{2}{|c|}{$\begin{array}{l}\text { Measured } \\
\text { ages/aBP }\end{array}$} & \multicolumn{2}{|c|}{$\begin{array}{c}\text { Calibrated } \\
\text { ages/cal aBP } \\
(1 \sigma)\end{array}$} \\
\hline & data & error & data & error & & data & error & data & error \\
\hline 10 & 507 & 60 & 530 & 30 & 200 & 5332 & 74 & 6095 & 105 \\
\hline 48 & 1154 & 65 & 1070 & 100 & 223 & 6903 & 75 & 7740 & 80 \\
\hline 98 & 3003 & 46 & 3205 & 65 & 250 & 9460 & 900 & $\mathrm{~T}$ & \\
\hline 133 & 4120 & 51 & 4595 & 65 & 275 & 10700 & 920 & $\mathrm{~T}$ & \\
\hline 163 & 4826 & 85 & 5560 & 100 & & & & & \\
\hline
\end{tabular}

\section{Experimental analysis and results}

The contents tested in laboratory comprised magnetic susceptibility, chemical elements, organic matter and granularity; these analyses were conducted by the Desert and Desertification Laboratory of Cold and Arid Regions Environmental and Engineering Institute, Chinese Academy of Sciences. Samples for magnetic susceptibility mensuration were firstly weighed by electronic balance of Denver Instrument XS-120(1/1000) type, secondly measured by Bartington magnetism instrument for 12 duplicates, and the result was the average. Samples for chemical element analysis need to be air-dried and ground into powder smaller than $74 \mu \mathrm{m}$ before measuring their contents with the fluorescence spectrometer of 3070E-X type (its measuring error is within 5\%), then to calculate the humid index according to the measured data. The organic matter content was measured with routine potassium di- chromate-sulfating titrimetric method, its error is within $0.2 \%$. A kind of laser granulometer made by Britain Malvern Corporation was used to measure the grain components, and its error is within $3 \%$.

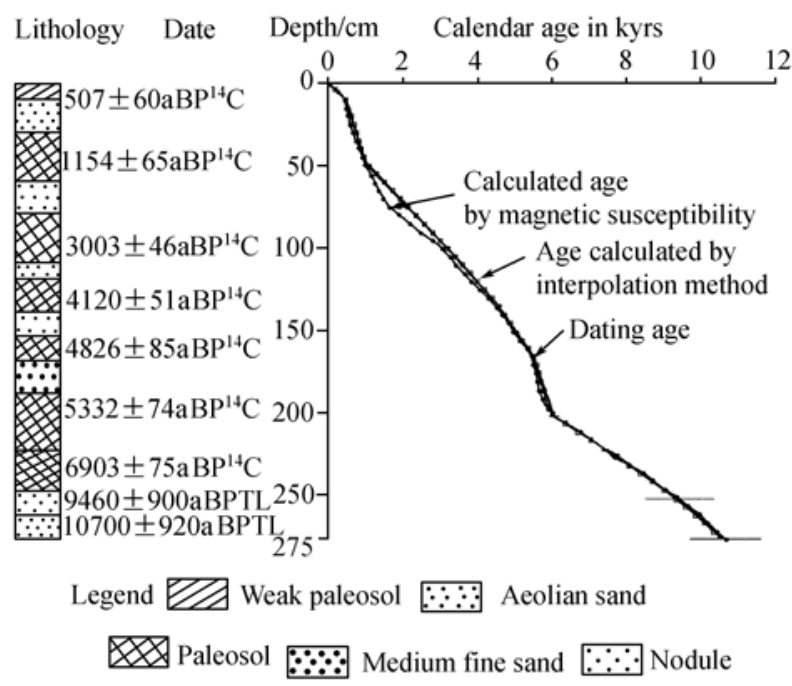

Fig. 2. Calculated stratigraphic era of Hunshandake Desert.

The experimental results are shown in Fig. 3, detecting that the magnetic susceptibility values of the typical Xilinhot profile range between $1.03 \times 10^{-4}$ and $9.58 \times 10^{-4}$ $\mathrm{SI} / \mathrm{g}$, the average is $3.98 \times 10^{-4} \mathrm{SI} / \mathrm{g}$. Comparatively, the magnetic susceptibility values of paleosol are higher, ranging between $2.16 \times 10^{-4}$ and $9.58 \times 10^{-4} \mathrm{SI} / \mathrm{g}$, averaging $4.64 \times 10^{-4} \mathrm{SI} / \mathrm{g}$, the standard deviation is $1.76 \times 10^{-4}$ $\mathrm{SI} / \mathrm{g}$; the magnetic susceptibility values of aeolian sand are 


\section{ARTICLES}

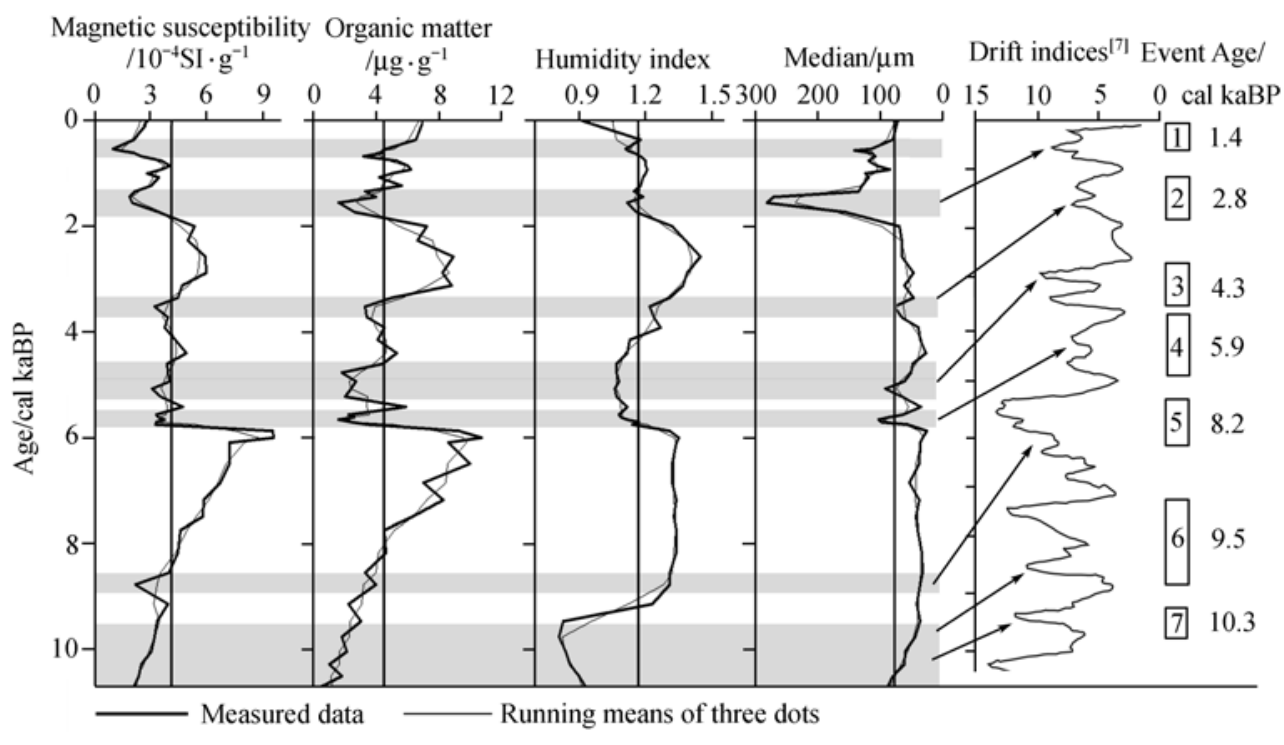

Fig. 3. Curves of climatic proxies changing along with time.

lower, ranging between $1.03 \times 10^{-4}$ and $4.06 \times 10^{-4} \mathrm{SI} / \mathrm{g}$, averaging $2.8 \times 10^{-4} \mathrm{SI} / \mathrm{g}$, the standard is $0.86 \times 10^{-4} \mathrm{SI} / \mathrm{g}$. Besides, it can also be known that the organic matter contents in the profile are in range of $0.5-10.7 \mu \mathrm{g} / \mathrm{g}$, with average of $4.64 \mu \mathrm{g} / \mathrm{g}$ and standard deviation of $2.47 \mu \mathrm{g} / \mathrm{g}$. For details, the content in paleosol is higher than that in aeolian sand, their range, average and standard deviation are $1.8-10.7,5.33,2.73$ and $0.5-4.6,2.76$, and 1.15 $\mu \mathrm{g} / \mathrm{g}$ respectively. Humidity index in the profile varied between $0.81-1.45$, with the average 1.17 , the standard deviation 0.15 . Although there is small variation extent of humidity index in profile, there still exists differentiation; generally higher value occurred in paleosol but lower value in aeolian sand, and their range, average and standard deviation are $0.81-1.37,1.2,0.18$ and $0.86-1.24$, $1.24,0.1$ respectively. The variation extent of average granularity in the profile is large, with ranges of 26-280 $\mu \mathrm{m}$, the average $77.45 \mu \mathrm{m}$ and standard deviation 50.67 $\mu \mathrm{m}$; being comparatively large in aeolian sand, the above three values are $51-280,111.9$ and $62.72 \mu \mathrm{m}$ in turn, which are smaller in paleosol, the three values are 26 $129,58.31$ and $29.06 \mu \mathrm{m}$ respectively.

Magnetic susceptibility is an ideal proxy reflecting climatic changes ${ }^{[13]}$. Former research results showed that eluviation played an important role in the increase of magnetic susceptibility value in strata resulting from the enrichment of magnetic minerals; the high the climatic humidity and the long the duration, the more the fine ferromagnetism minerals and the high the susceptibility values. Therefore, magnetic susceptibility is not only an index reflecting pedogenetic degree but also an index indicating summer monsoon intensity ${ }^{[14,15]}$. Showed by the measured results of stratigraphic magnetic susceptibility in Hunshandake Desert, there existed a process of wavely increasing converted to wavely decreasing at about $6 \mathrm{kaBP}$, suggesting that the summer monsoon gradually strengthened before $6 \mathrm{kaBP}$, then weakened down from then on. For details, the whole process falls into several strong phases and weak phases: ( $\mathrm{i}$ ) weak summer monsoon phases, they are $10.7-9.6,9-8.5,6-5.7,5.2-4.3$, $3.8-3.4,2.9-1.3$ and $0.7-0.3 \mathrm{kaBP}$, during which stratigraphic magnetic susceptibility was lower; (ii) strong summer monsoon phases, they are 9.6-9, 8.5-6, 5.75.2, 4.3-3.8, 3.4-2.9 and $1.3-0.7 \mathrm{kaBP}$, during which stratigraphic magnetic susceptibility was higher.

Humidity index is a proxy indicating climatic change between arid and humid, and it is expressed by the ratio of humid-indicating element content ( $\mathrm{Fe}, \mathrm{Al}, \mathrm{Mn}, \mathrm{Cr}, \mathrm{Co}, \mathrm{Ni}$ ) divided by arid-indicating element content $(\mathrm{K}, \mathrm{Na}, \mathrm{Ca}, \mathrm{Mg}$, $\mathrm{Sr}, \mathrm{Ba})^{[16]}$. In semi-humid and semi-arid regions the arid-indicating elements are easily to be eluviated when precipitation increasing, which results in the increase of humidity index value; contrarily in arid period with less precipitation the value of humidity index decreases due to less arid-indicating elements washed off. So, humidity index can be regarded as the indicator reflecting precipitation change. The variation sequence of humidity index in Xilinhot profile falls into six phases, among which phases of 9-6, 3.8-1.8 and 1.3-0.7 kaBP showed larger humidity indexes, reflecting humid climate; phases of $10.7-$ 9, 6-3.8, 1.8-1.3 kaBP and after $0.7 \mathrm{kaBP}$ showed smaller humidity indexes, indicating arid climate.

Organic matter content is regarded as the index indicating vegetation coverage and biomass ${ }^{[17-19]}$; the average 
granularity $(\mathrm{Mz})$ of sediments is a proxy reflecting wind $\operatorname{grade}^{[20,21]}$. The former can directly reflect the growth status of ground surface vegetation; the later hints the vicissitude of winter monsoon. The application of the above two indexes on reestablishing past climatic events has been successfully demonstrated by researches in refs. [17-21]. In Hunshandake Desert the organic matter enriched in paleosol and thinned in aeolian sand; its vertical distribution in profile quite accorded with that of magnetic susceptibility. The average granularity of sediments in the strata showed an increasing trend from profile bottom to top as a whole, indicating an intensifying trend of winter monsoon. Nevertheless, there existed fluctuations: during periods of $10.7-9.6,6-5.7,5.2-4.3,3.8-3.4,2.9-1.3$ and $0.7-0.3 \mathrm{kaBP}$, the average granularity increased and winter monsoon strengthened; during periods of $9.6-6$, $5.7-5.2,4.3-3.8,3.4-2.9,1.3-0.7 \mathrm{kaBP}$ and after 0.3 $\mathrm{kaBP}$, the average granularity decreased and winter monsoon weakened.

\section{Results and discussion}

( i ) General characteristics of Holocene climate change. Suggested by the changing regularity of the above proxies in Xilinhot profile in Hunshandake Desert, the Holocene summer monsoon generally had undergone processes from gradually boosting up to weakening down, its turning point was at $6 \mathrm{kaBP}$, but actually the changing processes fluctuated; the winter monsoon continuously strengthened as a whole; change of ground vegetation was similar to that of summer monsoon, so was the humidity index except for a little differentiation. In light of characteristics on summer monsoon or winter monsoon intensity and variation of ground vegetation and climate humidity, the climate changing processes in Hunshandake Desert can be divided into four periods: (1) The early Holocene period (10.7-9 kaBP). The summer monsoon intensity and vegetation coverage all increased gradually, on the other hand winter monsoon weakened. But the climate humidity greatly decreased for some reason. Generally, it was a period with weak summer monsoon, sparse vegetation and arid climate. (2) The Holocene Megathermal Maximum (9-6 kaBP). A period of popularizing summer monsoon, feeble winter monsoon, sparse vegetation and arid climate. (3) The middle Holocene period (6-3.4 $\mathrm{kaBP})$. Summer monsoon intensity, vegetation coverage and climate humidity fluctuated frequently. Generally it was an arid and cold climate period, during which both summer monsoon and winter monsoon were weak, and ground vegetation grew sparsely. (4) The late Holocene period (since $3.4 \mathrm{kaBP}$ ). A period of summer monsoon wavely weakened, winter monsoon gradually strengthened and climate fluctuately aridified.

(ii) Response of climatic change in Hunshandake Desert to global change. The Holocene climatic change in Hunshandake Desert accorded with the global climatic change.

During the early Holocene period, the global air temperature began to go up, but the absolute temperature value was relatively low. The aeolian sand deposition records in Hunshandake Desert indicated an arid-cold climate; humidity index analysis suggested that this period was the aridest time in Holocene, but winter monsoon has weakening trend, and summer monsoon gradually intensified and ground vegetation was in recovering situation. The climatic change during the early Holocene period in the Mu Us Desert was much similar to that in the study region ${ }^{[22]}$. At the same time the Indian monsoon intensified ${ }^{[23]}$, but the air temperature was relatively low, in North Atlantic there appeared two ice-floating events at 10.3 and $9.5 \mathrm{kaBP}^{[7]}$.

During the Holocene Megathermal Maximum, paleosol developed in Hunshandake Desert region but at low degree in prophase. The winter monsoon was always weak whereas the summer monsoon was strong through the period. Showed in Fig. 3, the summer monsoon-weakening phenomenon appeared at early $8.5 \mathrm{kaBP}$, which paralleled the 5th ice-floating event in North Atlantic. In this period the climate was warm in Chinese Loess Plateau ${ }^{[3]}$, and even in whole northern China ${ }^{[2,24]}$; the summer monsoon in southwest China was strong ${ }^{[25]}$. In global scale, the Indian summer monsoon boosted up to reach the maximum during $9.7-5 \mathrm{kaBP}$ in spite of several fluctuations in the period ${ }^{[23]}$. Accordingly, the precipitation in Indian Thar Desert increased, which resulted in the abrupt rise of lake level in this region ${ }^{[26]}$.

Entering the middle Holocene period, the climate in Hunshandake Desert suddenly became arid and fluctuated frequently. There had accumulated three aeolian sand layers overlapping two paleosol layers, which reflected three arid-climate events due to feeble summer monsoon, and two relatively humid-climate events in stronger summer monsoon. The climate changing processes were also supported by the variation sequence of magnetic susceptibility and organic matter content, only their values were low through the profile. Besides, the humidity index was also low. These evidences suggested that the climate had arid-cold prone characteristics. Contemporarily, climatic change in the $\mathrm{Mu}$ Us Desert had similar characteristics ${ }^{[22]}$, arid event occurred all over the Inner Mongolia region [27]; the southwest monsoon weakened steadily ${ }^{[25]}$. Correlatively, the Indian monsoon weakened all of a sudden at about $4.3 \mathrm{kaBP}^{[23]}$; consequently, the lakes in Thar Desert rapidly shrank since $4200 \mathrm{BC}$, and entirely dried up till $3500 \mathrm{BC}^{[26]}$. Two of the three arid-climate events in Hunshandake Desert respectively corresponded to the two ice-floating events happening in North Atlantic at 5.9 and $4.3 \mathrm{kaBP}^{[7]}$.

During the late Holocene period, the Hunshandake Desert had developed three paleosol and two aeolian sand 
layers. Upwards in strata proxies as magnetic susceptibility, organic matter content and humidity all wavely decreased, only the average granularity increased fluctuately. These indicated that the summer monsoon intensity gradually weakened and winter monsoon became predominant, resulting in climate aridifying and the vegetation coverage became smaller and smaller. For details, (1) during 3.4-1.8 kaBP both the summer monsoon intensity and vegetation coverage were large, which were only smaller than those in Holocene Megathermal Maximum, and the humidity index was even higher than those. The climate in this stage was warm and humid. In China region, paleosol broadly developed in hinterland areas during this stage, such as in the sandlands in Qinghai Gonghe Basin, in the Mu Us Desert and in the Loess Plateau ${ }^{[22,24]}$; in Gansu Minqin Basin there were other records of organic matter content increasing in lacustrine sediments of $2.8-2.1 \mathrm{kaBP}$ period. These proofs suggested that summer monsoon almost dominated China territory and brought about more precipitation ${ }^{[9]}$. At the same time the Indian summer monsoon was also strong ${ }^{[23]}$. (2) During 1.8 - $1.3 \mathrm{kaBP}$, the Hunshandake Desert strata teemed with aeolian sand, the changing curves of climate proxies showed that magnetic susceptibility, organic matter content and humidity displayed remarkable valley values, and the average granularity reflecting winter monsoon became the biggest in Holocene. Viewing from larger spatial scales, cold events occurred in many regions of China during $240-800 \mathrm{AD}^{[28]}$, and even a cold climate event during 1.8-1.4 kaBP had been recorded in the south deep sea of the Iceland ${ }^{[29]}$; besides, another ice-floating event appeared in North Atlantic at $1.4 \mathrm{kaBP}^{[7]}$ (Fig. 3). (3) During $1.3-0.7 \mathrm{kaBP}$, paleosol again developed in the strata of Hunshandake Desert; curves of magnetic susceptibility, organic matter content and humidity index showed peaks, but the absolute values of susceptibility and humidity index all approximated the average of Holocene expect for granularity surpassing the average of Holocene. It was deduced that in this stage winter monsoon intensified, summer monsoon was feeble; the humidity degree was not high but favourable for plant growth. Meanwhile, warming event happened in Daihai Lake in the southern part of the study region during $1.2-0.9 \mathrm{kaBP}^{[30]}$, and most of the China region had the warming event records during 800 $1400 \mathrm{AD}^{[28]}$, even the track records had been discovered all over the world ${ }^{[29,31,32]}$, which indicated that this was the Mediaeval Warm Period. (4) During 700-200 aBP, aeolian sand again deposited in Hunshandake Desert; the stratigraphic susceptibility, organic matter content and humidity index all distinctly decreased, whereas the average granularity remarkably increased. These had recorded the last cold event. Besides, more records of this cold event had been discovered in China region and even in

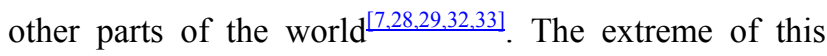
cold event took place at about $400 \mathrm{aBP}$, corresponding to the Little Ice Age cold event. Since the Little Ice Age although the Hunshandake Desert had developed original paleosol, accordingly the magnetic susceptibility and organic matter content gradually increased or the average granularity decreased, the humidity index was still in descending trend steadily. These proved that the summer monsoon was intensifying or the winter monsoon was weakening, as a result the climate kept persisting aridifying.

(iii) The summer monsoon changing characteristics on millenary time scale. Suggested by the geological data sequences in Hunshandake Desert, the Holocene summer monsoon had experienced many times strong-weak fluctuated in larger range. On the whole, the summer monsoon wavely strengthened before $6 \mathrm{kaBP}$ and weakened since then (Fig. 3). The changing regularity showed that the Holocene climate process fall into six periods when summer monsoon prevailed but winter monsoon retreated, and seven periods when winter monsoon re-invaded but summer monsoon fell into a decline. During summer monsoon prevailing periods the climatic humidity degree and vegetation coverage were relatively high, and vice versa. Further, the vicissitude of monsoon well correlated with the global change. It is obvious that factors controlling the climatic change of the study region mainly are the global change especially the East Asia monsoon variation.

According to the age mode, analysis on magnetic susceptibility power spectrum showed that there were two periodicities, 1465 and $494 \mathrm{a}$, in the changing series of summer monsoon intensity (Fig. 4), and they all have passed the Red Noise test of $90 \%$ confidence degree. The 1456-a period approximates to the 1450 -a period of the North Atlantic Ice floating event and to the arid-humid cycle of $1450-1470$ a in Arabia ${ }^{[8,34]}$; the 494 -a period

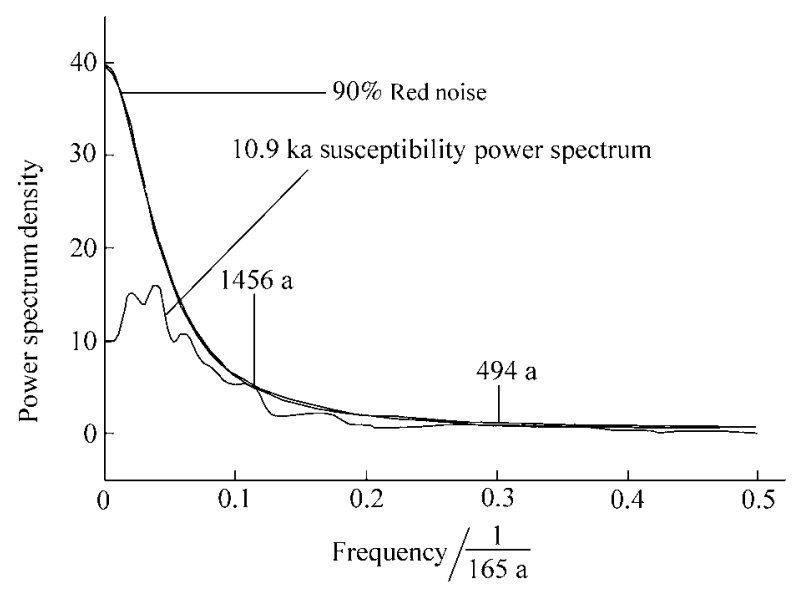

Fig. 4. The magnetic susceptibility power spectrum of Xilinhot profile. 
approximates to the world-accepted 512-a period having relation to the instability of warm current in North Atlantic ${ }^{[35]}$.

This study also proved that the Holocene summer monsoon variation of Hunshandake Desert coincided with the Indian monsoon change, illustrating that the driving mechanism of Asian monsoon is the same; the arid events of the study area coincided with the cold events in North Atlantic and arid events in middle to low latitudinal zones, which indicated that the periodical change of Holocene climate in Hunshandake Desert has global significance.

Acknowledgements This work was supported by the China Key Fundamental Developing Project (Grant No. G2000048701), the Chinese Post-Doctor Science Fund (Grant No. 200303440) and the Knowledge Innovation Engineering Project of Cold and Arid Regions Environmental and Engineering Institute of Chinese Academy of Sciences.

\section{References}

1. O’Brien, S. R., Mayewski, P. A., Meeker, L. D. et al., Complexity of Holocene climate as reconstructed from a Greenland ice core, Science, 1995, 270: 1962-1964.

2. An, Z., Porter, S. C., Kutzbach, J. E. et al., Asynchronous Holocene optimum of the East Asian monsoon, Quaternary Science Review, 2000, 19: 743-762. [DOI]

3. Xiao, J., Nakamura, T., Lu, H. et al., Holocene climate changes over the desert and loess transition of north-central China, Earth and Planetary Science Letters, 2002, 197: 11-18. [DOI]

4. Masson, V., Vimeux, F., Jouzel, J. et al., Holocene climate variability in Antarctica based on 11 ice-core isotopic records, Quaternary Research, 2000, 54: 348-358. [DOI]

5. Zhou, W. J., Lu, X. F., Wu, Z. K. et al., Peat record reflecting Holocene climatic change in Zoige Plateau and AMS rediocarbon dating, Chinese Science Bulletin, 2002, 47(1): 66-70. [Abstract] [PDF]

6. Brachfeld, S. A., Banerjee, S. K., Guyodo, Y. et al., A 13200 year history of century to millennial-scale paleoenvironmental change magnetically recorded in the Palmer Deep, western Antarctic Peninsula, Earth and Planetary Science Letters, 2002, 194: 311-326. [DOI]

7. Bond, G. C., Shower, W., Cheseby, M. et al., A pervasive millennial-scale in north Atlantic Holocene and glacial climates, Science, 1997, 278: 1257-1266. [DOI]

8. Pinegina, T. K., Bourgeois, J., Bazanova, L. I. et al., A millennial-scale record of Holocene tsunamis on the Kronotskiy bay coast, Kamchatka, Russia, Quaternary Research, 2003, 59: 36-47. [DOI]

9. Chen, F. H., Zhu, Y., Li, J. J. et al., Abrupt Holocene changes of the Asian monsoon at millennial- and centennial-scales: evidence from Lake Sediment document in Minqin Basin, North China, Chinese Science Bulletin, 2001, 46(23): 1942-1947. [Abstract] [PDF]

10. Li, S., Sun, W., Li, X. Z. et al., Deposition features and environmental evolution of Hunshandake Desert in Holocene, Journal of Desert Research (in Chinese), 1995, 15(4): 323-331.

11. Cui, H. T., Lui, H. Y., Yao, X. S., The finding of a paleo-spruce timber in Hunshandake sandy land and its paleoecological significance, Science in China, Series D, 1997, 40(6): 599-604.

12. Liu, H. Y., Xu, L. H., Cui, H. T., Holocene history of desertification along the woodland-steppe border in north China, Quaternary Research, 2002, 57: 259-270 [DOI].

13. Kukla, G., Heller, F., Liu, X. M. et al., Pleistocene climates in China dated by magnetic susceptibility, Geology, 1988, 16: 811814. [DOI]

14. Liu, X. M., Liu, D. S., John, S., Magnetic mineral characters of China loess and its paleaoclimate significance, Quaternary Research (in Chinese), 1993, (3): 281-287.

15. An, Z. S., Porter, S., Kukla, G. et al., Magnetic susceptibility proofs on monsoon change in recent 130000 years on Loess Plateau, Chinese Science Bulletin (in Chinese), 1990, 35(7): 529-532.

16. Huang, R. C., Palaeoclimate evolution documented by the elementary migration and conglomeration in terrestrial sediments, Memories of Lanzhou Institute of Geology, Academia Sinica, Beijing: Science Press, 1982, 137-160.

17. Gasse, F., Arnold, M., Fontes, J. C., A 13000-year climate record from west Tibet, Nature, 1991, 353: 742-745. [DOI]

18. Zhou, W. J., Donahue, D., Porter, S. C. et al., Variability of monsoon climate in east Asia at the end of the last glaciation, Quaternary Research, 1996, 46: 219-229. [DOI]

19. Zaady, E., Offcer, Z. Y., Shachak, M., The content and contributions of deposited aeolian organic matter in a dry land ecosystem of the Negev Desert, Israel, Atmospheric Environment, 2001, 35: 769-776. [DOI]

20. Lu, H. Y., An, Z. S., Paleoclimatic significance of grain size of loess-palaeosol deposit in Chinese Loess Plateau, Science in China, Series D, 1998, 41(6): 626-631.

21. Xiao, J. L., Porter, S. C., An, Z. S. et al., Grain size of quartz as an indicator of winter monsoon strength on the loess Plateau of central China during the last 130000 Year, Quaternary Research, 1995, 43: 22-29. [DOI]

22. Gao, S. Y., Chen, W. N., Jin, H. L. et al., Holocene primary study of the desert evolution in southwestern edge of monsoon regions, China, Science in China, Ser. B (in Chinese), 1993, 23(2): 202208.

23. Hong, Y. T., Hong, B., Lin, Q. H. et al., Correlation between Indian Ocean summer monsoon and north Atlantic climate during Holocene, Earth and Planetary Science Letters, 2003, 211: 371-380. [DOI]

24. Shi, Y. F., Kong, Z. C., Wang, S. M., Climates and environments of the Holocene megathermal maximum in China, Science in China, Series B, 1994, 37(4): 481-493.

25. Cai, Y. J., Peng, Z. C., An, Z. S. et al., The ${ }^{18} \mathrm{O}$ variation of a stalagmite from Qixingcave, Guizhou Province and indicated climate change during Holonece, Chinese Science Bulletin, 2001, 40(22): 1904-1907. [Abstract] [PDF]

26. Enzel, Y., Ely, L. L., Mishra, S. et al., High-resolution Holocene environmental changes in the Thar Desert, northwestern India, Science, 1999, 284: 125-127. [DOI]

27. Chen, C. T. A., Lan, H. C., Lou, J. Y. et al., The dry Holocene Megathermal in Inner Mongolia, Palaeogeography, Palaeoclimatology, Palaeoecology, 2003, 193: 181-200. [DOI]

28. Yang, B., Braeuning, A., Johnson, K. R., General characteristics of temperature variation in China during the last two millennia, Geophysical Research Letters, 2002, 29: 381-384.

29. Bianchi, G. G., Mccave, I. N., Holocene periodicity in north Atlantic climate and deep-ocean flow, south of Iceland, Nature, 1999, 397: 515-516. [DOI]

30. Jin, Z. D., Shen, J., Wang, S. M., The medieval warm period in the Daihai area, Journal of Lake Science (in Chinese) , 2002, 14(3): $209-216$.

31. Stuiver, M., Braziunas, T. F., Grootes, P. M., Is there evidence for solar forcing of climate in the GISP2 oxygen isotope record? Quaternary Research, 1997, 48: 259-266. [DOI]

32. Cronin, T. M., Dwyer, G. S., Kamiya, T. et al., Medieval warm period, litter ice age and 20th century temperature variability from Chesapeake Bay, Global and Planetary Change, 2003, 36: 17-29. [DOI]

33. Wang, S. W., Ye, J. L., Gong, D. Y., Climate in China during little ice age, Quaternary Research (in Chinese), 1998, 18(1): 54-64.

34. Sirocko, F., Garbe-Schonberg, D., McIntyre, A. et al., Teleconnections between the subtropical monsoon and high-latitude climates during the last deglaciation, Scinece, 1996, 272: 526-529.

35. Stuiver, M., Braziunas, T., Sun, Ocean, Climate and atmospheric ${ }^{14} \mathrm{CO}_{2}$ : An evaluation of causal and spectral relationship, Holocene, 1993, 3(4): 289-305.

(Received December 1, 2003; accepted April 28, 2004) 